\title{
Influence of small-scale patchiness on resilience of nutrient cycling to extended hypoxia in estuarine sediments
}

\author{
Joanne L. Banks ${ }^{1, *}$, D. Jeff Ross ${ }^{2}$, Michael J. Keough ${ }^{1}$, Catriona K. Macleod ${ }^{2}$, \\ Bradley D. Eyre ${ }^{3}$ \\ ${ }^{1}$ Department of Zoology, University of Melbourne, Melbourne, Victoria 3010, Australia \\ ${ }^{2}$ Institute of Marine and Antarctic Studies, Nubeena Crescent, Taroona, Tasmania 7053, Australia \\ ${ }^{3}$ Centre for Coastal Biogeochemistry, School of Environmental Science and Management, Southern Cross University, \\ PO Box 157, Lismore, New South Wales 2480, Australia
}

\begin{abstract}
Although much work has been done to predict the effects of hypoxia (dissolved oxygen $<2 \mathrm{mg} \mathrm{l}^{-1}$ ) at regional scales, individual estuaries consist of a patchwork of micro-environments that can have different responses. We followed the effects of extended dissolved oxygen (DO) depletion on benthic fluxes of $\mathrm{CO}_{2}, \mathrm{O}_{2}, \mathrm{NO}_{3}{ }^{-}, \mathrm{NH}_{4}{ }^{+}, \mathrm{N}_{2}, \mathrm{PO}_{4}{ }^{3-}$ and $\mathrm{Fe}$ from estuarine sediments from 3 shallow sites with different macrofauna communities and levels of organic enrichment. DO depletion was achieved by a prolonged $(40 \mathrm{~d})$ dark incubation of sealed sediment cores. There were no discernible differences in $\mathrm{NO}_{3}{ }^{-}$and $\mathrm{N}_{2}$ fluxes between sites, but the effects of hypoxia on sediment metabolism, and on bioavailable nutrient release, $\mathrm{NH}_{4}{ }^{+}$and $\mathrm{PO}_{4}{ }^{3-}$, were modified by the initial macrofauna communities. The DO in cores containing sediments from a site dominated by small epifauna declined significantly faster than in cores containing a greater portion of burrowing infauna; burrows may provide an oxic reservoir within the sediments. Macrofauna mortality led to a more rapid efflux of mineralization products $\left(\mathrm{CO}_{2}, \mathrm{NH}_{4}{ }^{+}\right.$and $\left.\mathrm{PO}_{4}{ }^{3-}\right)$ in the epifaunadominated sites, as the small surface-dwelling animals decomposed more quickly. However, the cores were sealed, preventing migration of mobile epifauna away from the hypoxic conditions. The site with the lowest abundance of macrofauna also contained a large amount of refractory organic matter. Decomposition of this material was slow, with little release of nutrients. The study highlights the fact that environmental patchiness can modify the effects of hypoxia and stresses the importance of deeper burrowing fauna as a buffer against declining DO conditions.
\end{abstract}

KEY WORDS: Hypoxia $\cdot$ Anoxia $\cdot$ Denitrification $\cdot$ DNRA $\cdot$ Organic enrichment $\cdot$ Benthic macrofauna

Resale or republication not permitted without written consent of the publisher

\section{INTRODUCTION}

Although hypoxia and anoxia have occurred in estuarine and coastal waters throughout time, the frequency and intensity of these events is increasing (Middelburg \& Levin 2009). Depletion of dissolved oxygen (DO) in estuarine waters typically occurs as a result of excessive nutrient loads triggering large increases in pelagic primary production and sub- sequent increased sedimentation of organic matter (OM) to the benthos (Diaz 2001). Oxygen deficiency in sediments results from decomposition of the excess $\mathrm{OM}$ by $\mathrm{O}_{2}$-utilising microbes (Schaanning et al. 1996). If natural mixing of waters occurs, either by tidal or wind-driven actions, then DO-depleted waters near the benthos can be re-oxygenated. However, density stratification, strengthened by seasonal inputs of fresh water and warming of surface waters, 
may impede downward mixing of $\mathrm{O}_{2}$ from surface waters (Kemp et al. 2009). DO conditions at the benthos determine whether sediments act as sinks or sources of nutrients, influencing the nutrient status of the overlying waters (Hietanen \& Lukkari 2007).

Recycling of dissolved inorganic nitrogen $(\mathrm{N})$ can exacerbate the effects of eutrophication and hypoxia by increasing primary production (Ferguson et al. 2004). A key process of $\mathrm{N}$ removal from nutrient-rich systems is sediment denitrification, whereby nitrate $\left(\mathrm{NO}_{3}{ }^{-}\right)$is reduced to $\mathrm{N}_{2}$. The $\mathrm{N}_{2}$ produced is mostly biologically unavailable, apart from to nitrogenfixing cyanobacteria, and even then the rates of fixation in the sediments of estuaries are low to moderate, except in highly organically enriched sediments (Howarth et al. 1988). The effects of DO depletion on denitrification are complicated. As denitrifying bacteria are facultative anaerobes their activity would be predicted to increase in low DO conditions. However, even short-term hypoxia can suppress nitrification in some systems (Abell et al. 2011). Once sediment and water column supplies of $\mathrm{NO}_{3}{ }^{-}$are exhausted, denitrification ceases and $\mathrm{N}$ is predominantly recycled as bioavailable ammonium $\left(\mathrm{NH}_{4}{ }^{+}\right)$(Kemp et al. 2009, Middelburg \& Levin 2009).

Under anaerobic conditions, $\mathrm{NO}_{3}{ }^{-}$may be reduced to $\mathrm{NH}_{4}{ }^{+}$in a process of dissimilatory nitrate reduction to ammonium (DNRA) (Silver et al. 2001). However, DNRA activity occurs predominantly in nitratelimited, carbon-rich environments (Tiedje 1988, Kelso et al. 1997) and where sulphide concentrations are high. In the absence of these conditions, DNRA is not thought to play an important quantitative role in estuarine sediments (Gilbert et al. 1997, Christensen et al. 2000).

Ammonium is also released to the water column during remineralisation of sedimentary $\mathrm{OM}$, together with bioavailable phosphate $\left(\mathrm{PO}_{4}{ }^{3-}\right)$ and $\mathrm{CO}_{2}$. Extended hypoxia and anoxia can lead to animal mortality, and the remineralisation of the biological material results in large pulses of both $\mathrm{NH}_{4}{ }^{+}$and $\mathrm{PO}_{4}{ }^{3-}$ to the water column. In addition, $\mathrm{PO}_{4}{ }^{3-}$ is released from sediment-bound ferric oxyhydroxide complexes in inorganic reduction reactions (Jordan et al. 2008). Increased benthic flux of $\mathrm{NH}_{4}{ }^{+}$and $\mathrm{PO}_{4}{ }^{3-}$ stimulates phytoplankton production, leading to further sedimentation of $\mathrm{OM}$, thereby promoting eutrophication processes and hypoxia in a positive feedback loop (Souchu et al. 1998, Hietanen \& Lukkari 2007).

The effects of DO depletion on benthic biogeochemical processes have largely been investigated by measuring nutrient fluxes in regions of season- ally recurring hypoxia, such as in the Gulf of Mexico (Childs et al. 2002, McCarthy et al. 2008), in and around the Baltic Sea (Hietanen \& Lukkari 2007, Conley et al. 2009b), and in Chesapeake Bay, USA (Kemp et al. 1990). Observations are often limited to a few sampling times, providing a snapshot of the response to depletion, rather than following the progressive effects of a DO depletion event from normoxic conditions, through hypoxia, culminating in anoxia. Furthermore, investigations into the response variability of sediments to hypoxia and anoxia have mainly focused on comparisons between regions (see Conley et al. 2009a, Kemp et al. 2009, Rabalais et al. 2010, Zhang et al. 2010), and less attention has been paid to small-scale variations within individual systems. For example, localised emissions of $\mathrm{OM}$ and nutrients, such as from pulp mills (PMs) and wastewater treatment plants (WWTPs), can lead to marked differences in sediment carbon enrichment within a small area (Oakes et al. 2010). Carbon enrichment increases sediment $\mathrm{O}_{2}$ demand, thereby escalating the opportunity for hypoxia to develop at those sites (Turner et al. 2008).

Another factor that may modify the benthic response to hypoxia is the presence of different functional groups of macrofauna. Macrofauna consume $\mathrm{O}_{2}$ directly via respiration and certain functional groups can also indirectly increase consumption via burrow construction and bioirrigation (Webb \& Eyre 2004, Braeckman et al. 2010). In contrast, by ventilating their burrows these groups transfer $\mathrm{O}_{2}$ down into the sediment, thereby creating a reservoir of oxic sediment and offering a buffer against the onset of hypoxia (Conley et al. 2009a). However, persistent hypoxia will negatively affect these activities and lead to either migration away from areas of hypoxia or mortality. Decomposition of dead biota subsequently increases $\mathrm{O}_{2}$ demands and releases bioavailable nutrients, further exacerbating eutrophication (Souchu et al. 1998).

In this study we hypothesised that the underlying ecological properties of sites within an estuary, specifically the OM content of the sediments and the quantity and types of macrofauna, would distinctly modify the sediment biogeochemical response to hypoxia and anoxia. We used laboratory cores to examine the effects of sustained DO depletion (40 d) on benthic fluxes from 3 shallow sites within a temperate urbanised estuary. The time scale of the experiment simulated a persistent seasonal hypoxic event, such as may occur in stratified temperate estuaries (Peña et al. 2010). 


\section{MATERIALS AND METHODS}

\section{Study area and site characteristics}

The Derwent estuary in Tasmania, southeastern Australia, is a temperate salt-wedge type estuary. It is $187 \mathrm{~km}$ in length and has a catchment area of $1427 \mathrm{~km}^{2}$. The middle part of the estuary is 1 to $2 \mathrm{~km}$ wide and has average water depths of 10 to $20 \mathrm{~m}$, and the estuary has a convoluted shoreline with numerous small, shallow embayments. Tides are generally small, with an average tidal range of $1 \mathrm{~m}$, and the average flushing period is $15 \mathrm{~d}$ (Butler 2006, Whitehead et al. 2010a). The estuary has fluctuating flow regimes as a result of variable rainfall and changing water requirements for hydroelectric generation and irrigation in the catchment. Wind is the primary mixing agent, and tidal mixing plays only a small part (Thomson \& Godfrey 1985). As a result of the low tidal flows and lack of mixing, the Derwent can be strongly stratified at times (Rochford 1951). Nutrient point sources along the estuary include 10 WWTPs, and a PM in the upper estuary. Between 2003 and 2008, average $\mathrm{NH}_{4}{ }^{+}$concentrations ranged from 2 to $30 \mu \mathrm{g} \mathrm{l}^{-1}$, and $\mathrm{PO}_{4}{ }^{3-}$ ranged from 2 to $18 \mu \mathrm{g} \mathrm{l^{-1 }}$. Generally, the highest concentrations of these ions were recorded in mid-estuary embayments (Whitehead et al. 2010b). Water column conditions in the Derwent are normally oxic, although during summer months, and under low flow conditions, average DO concentrations of $4 \mathrm{mg} \mathrm{l}^{-1}(\sim 45 \%$ saturation) have been recorded (Whitehead et al. 2010b). Although hypoxia and nuisance algal blooms have not been a major concern in the Derwent to date, continued development is predicted to result in further nutrient inputs, which could increase the risk of excessive algal growth, eutrophication and hypoxia.

Sediment cores were collected in August 2010 from 3 shallow ( 10 m), muddy sites (particle size $60 \%<63 \mu \mathrm{m})$ at the mouths of 3 mid-estuary embayments: Elwick Bay (EB) $\left(42^{\circ} 49^{\prime} 1.79^{\prime \prime} \mathrm{S}\right.$, $\left.147^{\circ} 16^{\prime} 34.74^{\prime \prime} \mathrm{E}\right)$, Geilston Bay (GB) $\left(42^{\circ} 50^{\prime} 38.77^{\prime \prime} \mathrm{S}\right.$, $\left.147^{\circ} 20^{\prime} 15.42^{\prime \prime} \mathrm{E}\right)$ and Ralph's Bay (RB) (42 $56^{\prime}$ $\left.43.11^{\prime \prime} \mathrm{S}, 147^{\circ} 25^{\prime} 31.26^{\prime \prime} \mathrm{E}\right)$. The experiment was carried out during the austral winter when DO concentrations in the bottom waters were above $70 \%$ saturation at all sites. This enabled us to monitor the gradual effects of DO depletion, from normoxic to hypoxic and anoxic conditions, on nutrient fluxes. The sites are representative of regions with (1) PM fibre enrichment and reduced macrofauna (EB), (2) relatively high nutrient inputs and abundant epifaunal macrofauna (GB) and (3) relatively low OM and nutrients and dense aggregations of burrowing macrofauna (RB) (Macleod \& Helidoniotis 2005).

\section{Field sampling}

Divers collected 5 replicate sediment cores from each of the 3 sites to a depth of $15 \mathrm{~cm}$, by using polycarbonate core tubes $(30 \times 15 \mathrm{~cm}$ diameter $)$. Cores were capped at both ends and returned to the laboratory in closed bins filled with water collected from near the bottom at each collection site. Ambient bottom water readings of DO saturation and salinity were recorded with an HACH (HQ40d) dual-input, multi-parameter, digital meter with DO (LDO101-15) and conductivity probes (CDC401-15) (Hach Company).

Six smaller sediment cores (Perspex tubes, $30 \times$ $5 \mathrm{~cm}$ diameter) were also collected at each site. Samples were processed on the boat immediately after collection as follows. Three replicate cores were used for measurement of redox potential and sediment sulphide concentration. Sediment was extruded up the column of the mini-core by using a wooden plunger to a level just above a $2 \mathrm{~cm}$ diameter hole drilled into the side for the insertion of probes (covered with masking tape when not in use). Probes were inserted into the sediment, at a depth of $1 \mathrm{~cm}$ from the sediment surface, until a stable value was attained. Redox potential was measured by using a WTW pH 320 meter with a Mettler Toledo Ag/AgCl combination $\mathrm{pH} / \mathrm{Redox}$ probe. The standard potential of the $\mathrm{Ag} / \mathrm{AgCl}$ reference cell of the probe is $207 \mathrm{mV}$ at $25^{\circ} \mathrm{C}$, which was the approximate temperature of the samples during measurement. Calibration and functionality of the meter were checked before each test using a redox buffer solution $\left(220 \mathrm{mV}\right.$ at $25^{\circ} \mathrm{C}$ ). Corrected redox potential values (Eh) were calculated by adding the standard potential of the reference cell to the measured redox potential and are reported in millivolts. A $4 \mathrm{ml}$ subsample of sediment was removed from the same core through the hole in the tube (at $1 \mathrm{~cm}$ depth) by using a syringe, for measurement of sulphide with a Cole-Parmer 27502-40 silver/sulphide electrode (unit of detection, $\mathrm{M}$; concentration range, 0.03 to 32100 ppm $\mathrm{S}^{2-}$ ) according to the methods described by Macleod et al. (2004).

The remaining 3 replicate cores were each used for analysis of total organic carbon (TOC), total nitrogen (TN), total phosphorous (TP) and particle size analysis, and one of the cores from each site was also analysed for sediment Fe. Samples were extracted 
from the surface sediment of each core by using $50 \mathrm{ml}$ syringes (with the syringe ends cut off). The syringes were inserted to a depth of $2 \mathrm{~cm}$ into the sediment core and the extracted sample extruded into separate acid-washed glass jars. Samples were kept on ice until return to the laboratory.

In order to characterise the macrofaunal assemblages at the study sites, 3 extra cores were collected at each site and the contents immediately transferred into $1 \mathrm{~mm}$ mesh nylon bags, sieved to remove the bulk of the sediment and fixed in $4 \%$ formalin buffered in seawater (it was not possible to measure macrofauna within the experimental cores, as only hard parts such as shells remained at the end of the incubation period). Macrofauna samples were rinsed and preserved in $70 \%$ ethanol prior to sorting and identification. Fauna were identified to the lowest practicable taxonomic level and enumerated.

\section{Laboratory incubations}

We tested the effects of depleting DO on sediment metabolism, denitrification and benthic fluxes during a $40 \mathrm{~d}$ sealed dark incubation. Samples were taken daily for a week and then at increasingly larger sample intervals thereafter until the final sampling at $40 \mathrm{~d}$. This design enabled us to measure the initial effects of DO depletion plus the on-going consequences of hypoxia.

In the laboratory, 5 cores collected from each site were immediately transferred into 3 separate tanks filled with water taken from near the bottom at each of the collection sites. At the start of the incubation period the cores were sealed with lids that included a Perspex stirring plate. The stirring velocity was set at a rate sufficient to keep the water volume within the sealed core moving without visibly disturbing the sediment. All incubations were done in the dark. Water samples $(200 \mathrm{ml})$ were taken through tapped inlet/outlet tubes in the core lids at each time period for nutrient $\left(\mathrm{NO}_{2}{ }^{-}, \mathrm{NO}_{3}{ }^{-}, \mathrm{NH}_{4}{ }^{+}, \mathrm{PO}_{4}{ }^{3-}\right)$, dissolved $\mathrm{N}_{2}$, $\mathrm{pH}$ and alkalinity analyses. The DO content of the water was measured at each sampling time by using the $\mathrm{HACH}$ probe.

Subsamples for $\mathrm{NO}_{3}{ }^{-}, \mathrm{NH}_{4}{ }^{+}, \mathrm{Fe}$ and alkalinity were filtered through Minisart Plus $0.45 \mu \mathrm{m}$ cellulose acetate filters into $10 \mathrm{ml}$ polypropylene vials. The samples for Fe analysis were immediately acidified with concentrated nitric acid $(1 \% \mathrm{v} / \mathrm{v}$, Merck GR). Samples for $\mathrm{pH}$ and dissolved $\mathrm{N}_{2}$ were unfiltered; $\mathrm{pH}$ samples were transferred into $10 \mathrm{ml}$ polypropylene vials and $\mathrm{N}_{2}$ samples into $7 \mathrm{ml}$ gas-tight glass vials. Alkalinity and $\mathrm{N}_{2}$ samples were preserved with 40 and $20 \mu \mathrm{l}$ of $25 \%$ saturated mercury chloride, respectively. Inorganic nutrient samples were frozen $\left(-20^{\circ} \mathrm{C}\right)$ in polypropylene vials until required for analysis. The $\mathrm{N}_{2}$ samples were stored submerged at in situ temperature until analysis. Header tanks containing site-specific bottom water were used to replace extracted sample volumes. As replacement water was added during sample withdrawal, samples of the header tank water were taken at 0,8 and $15 \mathrm{~d}$ to calculate any possible background concentrations of nutrients. At the end of the incubation, sediment surface samples $(0$ to $2 \mathrm{~cm}$ depth) were extracted from each core for analysis of TOC, TN, TP, Eh and $\mathrm{S}^{2-}$.

\section{Sample analysis}

Alkalinity and $\mathrm{pH}$ were measured by using Gran titration performed with a Metrohm Auto titration System (Metrohm). Dissolved nutrients were measured with a flow injection analyser (FIA) (Quick Chem 8000, Lachat Instruments) using American Public Health Association (APHA) standard methods (Eaton et al. 2005).

Denitrification was estimated by directly measuring $\mathrm{N}_{2}$ fluxes obtained from the $\mathrm{N}_{2}$ : Ar ratios of the dissolved $\mathrm{N}_{2}$ water samples by using the method and instrumentation of Kana et al. (1998) with the modifications described by Eyre et al. (2002). $\mathrm{N}_{2}$ effluxes represent the balance between fixation and production processes. As we were unable to separate these processes we used the $\mathrm{N}_{2}$ flux data in terms of net denitrification, i.e. minus any fixation activity. In addition, $\mathrm{N}_{2}$ effluxes included all $\mathrm{N}_{2}$-producing processes including anammox; however, the contribution of anammox to $\mathrm{N}_{2}$ effluxes in shallow sediments was expected to be small (Dalsgaard et al. 2005).

TOC in sediments was analysed using the National Environment Protection Council (NEPC) method 105 by using a colourmetric endpoint. Results are reported as $\mathrm{g} \mathrm{C} \mathrm{kg}^{-1}$ sediment, with a minimum reporting limit of $1 \mathrm{~g} \mathrm{C} \mathrm{kg}^{-1}$. TN in sediments was calculated by adding oxides of nitrogen (determined from a $2 \mathrm{M}$ $\mathrm{KCl}$ extraction) to the total Kjeldahl nitrogen (TKN) present in the sample measured using the APHA standard methods. Results are reported as $\mathrm{g} \mathrm{N} \mathrm{kg}^{-1}$ sediment, with a minimum reporting limit of $0.1 \mathrm{~g}$ $\mathrm{N} \mathrm{kg}^{-1}$. Phosphorus compounds were converted to orthophosphate in a Kjeldahl digest, and the resulting solution was analysed by flow injection analysis. This method was developed by Lachat Instruments 
and is a combination of 'Quikchem' Method 10-11501-1-C and Method 10-107-06-2-E. Results are reported as $\mathrm{g} \mathrm{P} \mathrm{kg}{ }^{-1}$ sediment, with a minimum reporting limit of $0.1 \mathrm{~g} \mathrm{P} \mathrm{kg}^{-1}$.

\section{Calculations}

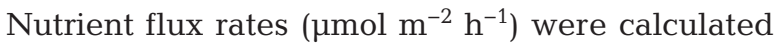
from the incubation time (i.e. the time between sampling efforts), the measured height of the water column in each core, the core sediment area and the concentration changes during incubation (minus concentrations added in the replacement water from header tanks during sampling). Nutrient concentrations below the detection limits of the FIA (0.002 mg $\mathrm{l}^{-1}$ ) were treated as zero when calculating fluxes.

$\mathrm{TCO}_{2}$ was calculated from $\mathrm{pH}$ and alkalinity fluxes according to Almgren et al. (1983); dissociation constants of carbonic acid were calculated according to Roy et al. (1993). The community respiratory quotient (CRQ) was calculated from the ratio of $\mathrm{CO}_{2}$ efflux to $\mathrm{O}_{2}$ consumption.

Denitrification efficiency (DNE) is defined as the proportion of $\mathrm{N}$ liberated as $\mathrm{N}_{2}$ compared with total DIN $\left(\mathrm{NO}_{2}{ }^{-}, \mathrm{NO}_{3}{ }^{-}, \mathrm{NH}_{4}{ }^{+}\right)$during metabolism where DNE $=\left[\mathrm{N}_{2}-\mathrm{N} /(\mathrm{DIN}\right.$ $\left.+\mathrm{N}_{2}-\mathrm{N}\right) \times 100 \%$ ] (Eyre \& Ferguson 2002, 2009).

\section{Statistical analysis}

Two-factor repeated-measures ANOVA was used to test the null hypothesis that DO depletion similarly affected benthic fluxes between sites. Individual cores were the subjects, site was the between-subjects factor and time was the within-subjects factor. All factors were fixed. Where significant interactions with time were detected, analyses were repeated separately by Day and post hoc Tukey's HSD tests performed to indicate site differences. All statistical analysis was carried out by using Systat v. 12 (Systat Software).

Error bars are not shown on the figures, because the SE bars normally presented about each mean are misleading in repeated-measures analyses. The hypothesis test of greatest interest, the Site $\times$ Time effect, was tested using as an error term, the variance through time among replicate mesocosms (see 'within-cores' MS on Table 2). The overall difference between sites was tested using the variation between average values of replicate mesocosm as its error term. Neither of these error terms is related to the conventional SE values about each Site-Time combination, so the relevant measures of variation are presented in the analysis table, rather than as a distracting form of error bar (see Quinn \& Keough 2002).

\section{RESULTS}

\section{Site and sediment characteristics}

RB sediment was muddy with low concentrations of TOC and $\mathrm{S}^{2-}$ (Table 1). GB sediment was also muddy and more reduced, and had greater concentrations of TN, TP, TOC and $\mathrm{S}^{2-}$ than the other 2 sites. EB cores were quite different, containing a layer of woody fibrous material at the surface and darker brown underlying muddy sediments. These sediments had the lowest redox potential and TP concentration and

Table 1. Geochemical properties of sediments and macrofauna abundance, diversity and biomass from 3 sites within the Derwent estuary, metals ( $\mathrm{n}=1)$ and geochemical properties $(n=3)$. Sulphide and redox measurements were taken at the beginning and end of the experiment. SE values of means are included where appropriate. RB: Ralph's Bay; GB: Geilston Bay; EB: Elwick Bay

\begin{tabular}{|c|c|c|c|c|}
\hline \multirow{2}{*}{ Feature } & \multirow{2}{*}{$\begin{array}{c}\text { Time of } \\
\text { measurement }\end{array}$} & \multicolumn{3}{|c|}{ Site } \\
\hline & & EB & GB & $\mathrm{RB}$ \\
\hline \multicolumn{5}{|l|}{ Macrofauna } \\
\hline \multicolumn{2}{|l|}{ Biomass ( $g$ wet weight $\mathrm{m}^{-2}$ ) } & $1.4 \pm 0.8$ & $8.1 \pm 2$ & $12.7 \pm 1.6$ \\
\hline \multicolumn{2}{|c|}{ Abundance (no. organisms $\mathrm{m}^{-2}$ ) } & $49 \pm 22$ & $1017 \pm 240$ & $810 \pm 112$ \\
\hline \multicolumn{2}{|l|}{ Species richness (per core) } & $2 \pm 1$ & $12 \pm 3$ & $17 \pm 1$ \\
\hline \multicolumn{2}{|l|}{ Epifauna proportion $(\%)^{\mathrm{a}}$} & - & $50 \pm 7$ & $15 \pm 5$ \\
\hline \multicolumn{5}{|l|}{ Sediment characteristics } \\
\hline \multicolumn{2}{|l|}{ Particles < 0.063 mm (\%) } & $74 \pm 2$ & $70 \pm 5$ & $69 \pm 7$ \\
\hline \multicolumn{2}{|l|}{ TOC $\left(\mathrm{g} \mathrm{C} \mathrm{kg}^{-1}\right)$} & $45 \pm 9$ & $52 \pm 4$ & $21 \pm 2$ \\
\hline $\mathrm{TN}\left(\mathrm{g} \mathrm{N} \mathrm{kg}^{-1}\right)$ & Start & $2.1 \pm 0.3$ & $3.9 \pm 0.4$ & $2.2 \pm 0.3$ \\
\hline $\mathrm{TP}\left(\mathrm{g} \mathrm{P} \mathrm{kg}^{-1}\right)$ & Start & $0.5 \pm 0.0$ & $1.4 \pm 0.2$ & $0.6 \pm 0.0$ \\
\hline $\mathrm{C}: \mathrm{N}$ ratio & Start & 21 & 13 & 9 \\
\hline $\mathrm{Fe}\left(\mathrm{g} \mathrm{kg}^{-1}\right)$ & Start & 24 & 43 & 27 \\
\hline \multirow[t]{2}{*}{ Eh $(\mathrm{mV})$} & Start & $23 \pm 13$ & $98 \pm 12$ & $130 \pm 9$ \\
\hline & End & $18 \pm 9$ & $64 \pm 3$ & $70 \pm 43$ \\
\hline \multirow[t]{2}{*}{ Sediment $\mathrm{S}^{2-}\left(\mathrm{mg} \mathrm{kg}^{-1}\right)$} & Start & $0.3 \pm 0.2$ & $0.9 \pm 0.7$ & 0 \\
\hline & End & $4.0 \pm 0.8$ & $1.2 \pm 0.5$ & $0.3 \pm 0.2$ \\
\hline \multirow[t]{2}{*}{ Water column $\mathrm{S}^{2-}\left(\mathrm{mg} \mathrm{l}^{-1}\right)$} & Start & 0 & 0 & 0 \\
\hline & End & 0 & $0.1 \pm 0.0$ & $0.7 \pm 0.3$ \\
\hline \multicolumn{5}{|c|}{$\begin{array}{l}\text { aA percentage epifauna value is not given for EB as only } 5 \text { species } \\
\text { were sampled in total ( } 3 \text { epifauna and } 2 \text { infauna species) and } 1 \text { site had } \\
\text { only } 1 \text { species sampled }\end{array}$} \\
\hline
\end{tabular}


the highest $\mathrm{C}: \mathrm{N}$ ratio, most probably owing to the layer of refractory wood pulp.

Macrofauna burrows were clearly visible to depths of 5 to $10 \mathrm{~cm}$ in the RB sediment, which was dominated by large burrowing maldanid polychaetes. Other macrofauna groups found within these sediments included terebellid and sabellid polychaetes, small nassarid gastropods, callianassids, crabs and bivalves. Smaller burrows to depths of $2 \mathrm{~cm}$ were visible in the GB sediments, and these were dominated by an invasive Japanese fanworm, Euchone limnicola, and small capitellid polychaetes. No burrows were apparent in the EB sediments, and this site had significantly lower species richness, diversity and biomass than the other 2 sites (Tables 1 \& 2), containing only a few E. limnicola, a shrimp and the invasive bivalve Theora lubrica. RB and GB had similar average macrofauna abundance and richness, but RB had the greatest biomass and GB sediments contained 3 times more epifauna than did RB.

After a week of sealed incubation with no $\mathrm{O}_{2}$ replenishment, large numbers of dead animals were observed on the surface of the RB and GB sediments. After 2 wk, black streaks were apparent in the RB sediments, indicating the location of former burrows, and the surface layers of $\mathrm{RB}$ and $\mathrm{GB}$ sediments were black. The EB sediments did not look significantly changed until Week 3, at which time a fine suspension of black sulphidic sediment coated the inside of the cores. By this stage the RB and GB cores appeared totally black. All cores emitted a strong smell of $\mathrm{H}_{2} \mathrm{~S}$ when opened after $40 \mathrm{~d}$ of $\mathrm{O}_{2}$ depletion, and EB sediments were significantly more reducing and sulphidic.

\section{Sediment metabolism}

The DO content of the overlying water fell rapidly in all of the cores (Fig. 1a). The greatest decline was measured in the water overlying GB sediments, which were hypoxic after $5 \mathrm{~d}$. DO depletion was slower in the $\mathrm{RB}$ and EB cores, with the overlying waters becoming hypoxic after $8 \mathrm{~d}$. There was a significant interaction between site and time for $\mathrm{O}_{2}$ consumption (Table 2). After the first day $\mathrm{O}_{2}$ consumption was approximately $50 \%$ higher in the GB sediments. After $2 \mathrm{~d}$, consumption in GB sediments was $90 \%$ higher than in EB and $35 \%$ higher than in $\mathrm{RB}$.

$\mathrm{CO}_{2}$ production was highly variable for all of the sites during the first week of the experiment (Fig. 1C). The average flux rates of $\mathrm{CO}_{2}$ from $\mathrm{GB}$ and $\mathrm{RB}$ sediments quadrupled by Day 15, and were 6 times higher from EB sediments. During the following week the mean flux of $\mathrm{CO}_{2}$ remained stable in $\mathrm{GB}$, declined by $50 \%$ in $\mathrm{EB}$ and increased by $50 \%$ in RB sediments.
Table 2. Values of $\mathrm{p}$ from single-factor ANOVA to test differences in macrofauna (MF) characteristics between sites (biomass, abundance and diversity) and from 2-factor repeated measures ANOVA for benthic fluxes $\left(\mathrm{O}_{2}, \mathrm{CO}_{2}\right.$, $\mathrm{NO}_{3}{ }^{-}, \mathrm{N}_{2}, \mathrm{NH}_{4}{ }^{+}, \mathrm{PO}_{4}{ }^{3-}, \mathrm{Fe}$ ) and community respiratory quotient (CRQ), denitrification efficiency (DNE) and alkalinity, and results of post hoc tests. The factor 'Site' is repeated across 11 time periods across $40 \mathrm{~d}$. Significant results are in bold text. RB: Ralph's Bay; GB: Geilston Bay; EB: Elwick Bay

\begin{tabular}{|c|c|c|c|c|c|}
\hline Parameter & $\begin{array}{c}\text { Site } \\
\text { p-value }\end{array}$ & $\begin{array}{l}\text { Between- } \\
\text { cores } \\
\text { error }\end{array}$ & $\begin{array}{l}\text { Time } \\
\text { p-value }\end{array}$ & $\begin{array}{l}\text { Time } \times \text { Site } \\
\text { p-value }\end{array}$ & $\begin{array}{c}\text { Within- } \\
\text { cores } \\
\text { error }\end{array}$ \\
\hline \multicolumn{6}{|l|}{ ANOVA results } \\
\hline MF biomass & 0.006 & 7 & & & \\
\hline MF abundance & 0.010 & 70359 & & & \\
\hline MF diversity & 0.003 & 9 & & & \\
\hline $\mathrm{df}$ & 2 & 12 & 10 & 20 & 120 \\
\hline DO & 0.000 & 1 & 0.000 & 0.000 & 0.2 \\
\hline $\mathrm{O}_{2}$ consumption & 0.020 & 14302 & 0.000 & 0.000 & 75038 \\
\hline $\mathrm{CO}_{2}$ & 0.013 & 24951 & 0.000 & 0.032 & 37959 \\
\hline CRQ & 0.002 & 1 & 0.000 & 0.000 & 3 \\
\hline $\mathrm{NO}_{3}^{-}$ & 0.005 & 6 & 0.000 & 0.078 & 28 \\
\hline $\mathrm{N}_{2}$ & 0.710 & 64 & 0.000 & 0.633 & 54 \\
\hline $\mathrm{NH}_{4}^{+}$ & 0.001 & 1659 & 0.000 & 0.000 & 786 \\
\hline DNE & 0.001 & 44 & 0.000 & 0.200 & 64 \\
\hline $\mathrm{PO}_{4}{ }^{3-}$ & 0.001 & 1 & 0.000 & 0.000 & 1 \\
\hline Alkalinity & 0.011 & 0.033 & 0.000 & 0.000 & 0.001 \\
\hline $\mathrm{Fe}$ & 0.000 & 3 & 0.000 & 0.000 & 24 \\
\hline \multicolumn{6}{|l|}{ Post hoc tests } \\
\hline MF biomass & \multicolumn{5}{|c|}{$\mathrm{EB}<\mathrm{GB}=\mathrm{RB}$} \\
\hline MF abundance & \multicolumn{5}{|c|}{$\mathrm{EB}<\mathrm{GB}=\mathrm{RB}$} \\
\hline MF diversity & \multicolumn{5}{|c|}{$\mathrm{EB}<\mathrm{GB}=\mathrm{RB}$} \\
\hline DO & \multicolumn{5}{|c|}{ Days 1-6: $\mathrm{GB}<\mathrm{EB}=\mathrm{RB}, \mathrm{D} 8: \mathrm{GB}<\mathrm{EB}$} \\
\hline $\mathrm{O}_{2}$ consumption & \multicolumn{5}{|c|}{ Days $1 \& 2: \mathrm{EB}=\mathrm{RB}<\mathrm{GB}$} \\
\hline $\mathrm{CO}_{2}$ & \multicolumn{5}{|c|}{$\begin{array}{l}\text { Day 15: } \mathrm{EB}=\mathrm{RB}<\mathrm{GB} ; \text { Day 22: } \mathrm{EB}<\mathrm{RB}=\mathrm{GB} \\
\text { Day 40: } \mathrm{EB}=\mathrm{GB}<\mathrm{RB}\end{array}$} \\
\hline CRQ & \multicolumn{5}{|c|}{ Day 40: $\mathrm{EB}<\mathrm{GB}=\mathrm{RB}$} \\
\hline $\mathrm{NH}_{4}^{+}$ & \multicolumn{5}{|c|}{ Days 3-6 \& 15: $\mathrm{EB}=\mathrm{RB}<\mathrm{GB}$; Day 22: $\mathrm{EB}<\mathrm{RB}=\mathrm{GB}$} \\
\hline $\mathrm{PO}_{4}{ }^{3-}$ & \multicolumn{5}{|c|}{ Day 3: $\mathrm{EB}<\mathrm{RB}=\mathrm{GB}_{i}$ Day 15: $\mathrm{EB}=\mathrm{RB}<\mathrm{GB}$} \\
\hline Alkalinity & \multicolumn{5}{|c|}{$\mathrm{EB}<\mathrm{RB}=\mathrm{GB}$} \\
\hline $\mathrm{Fe}$ & \multicolumn{5}{|c|}{ Day 6: $\mathrm{EB}<\mathrm{RB}$; Day 22: $\mathrm{EB}<\mathrm{RB}<\mathrm{GB}$; Day 40: $\mathrm{RB}<\mathrm{EB}$} \\
\hline
\end{tabular}



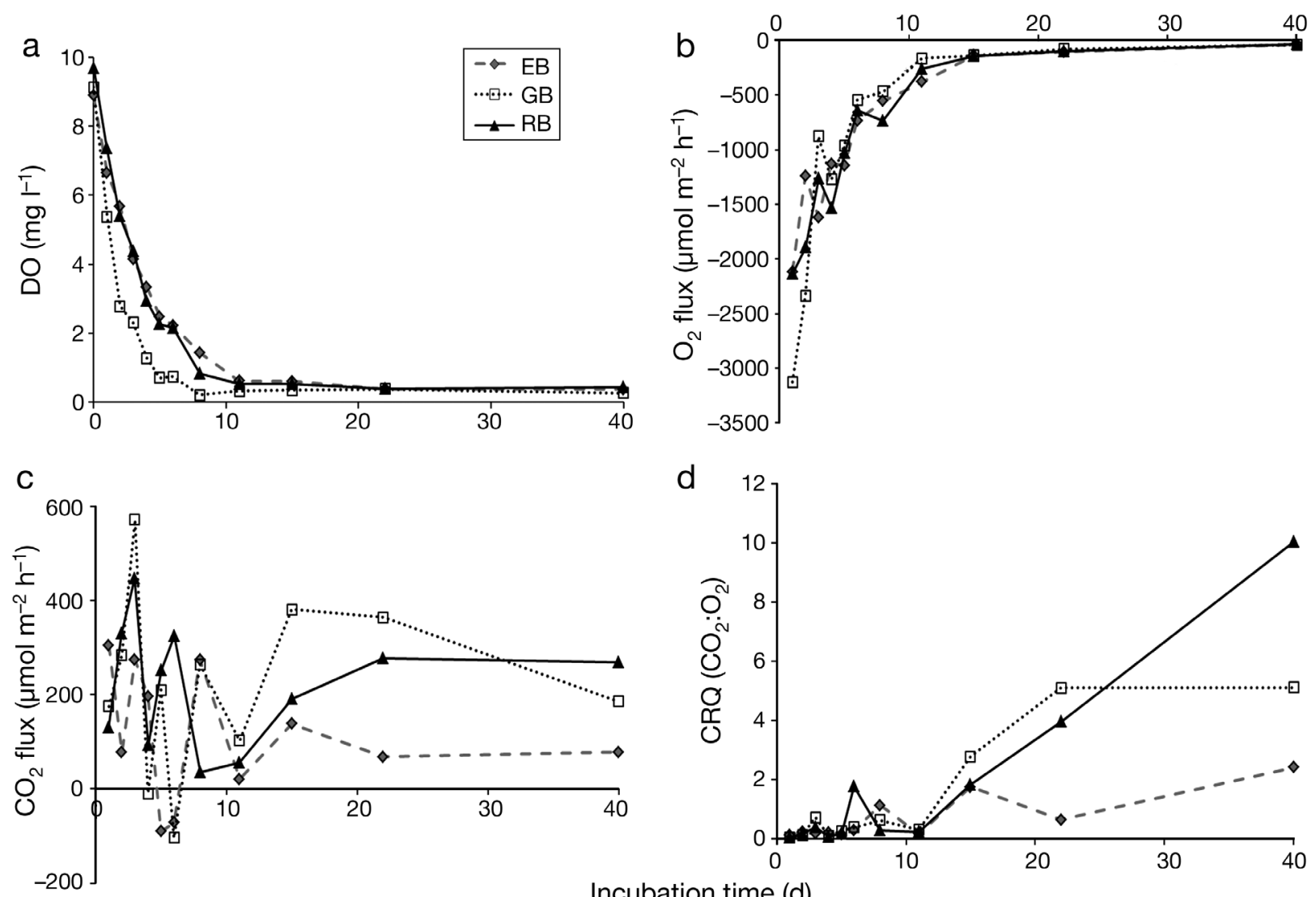

Fig. 1. (a) Mean dissolved oxygen (DO) concentration in water overlying sediments, (b) $\mathrm{O}_{2}$ consumption, (c) $\mathrm{CO}_{2}$ production and (d) community respiratory quotient (CRQ) of core sediments collected from 3 bays in the Derwent estuary and incubated in laboratory cores in the dark for $40 \mathrm{~d}$ (see text regarding omission of error bars in repeated measures designs). RB: Ralph's Bay; GB: Geilston Bay; EB: Elwick Bay

There was a site and time interaction in the ratio of $\mathrm{CO}_{2}$ produced to $\mathrm{O}_{2}$ consumed (CRQ) (Table 2). The CRQ increased across all sites from Day 11 (Fig. 1d). However, only Day 40 results were significantly different, in which RB CRQ was higher than those in EB and GB.

\section{Nitrogen fluxes}

Nitrate production varied significantly between sites and across time (Table 2). Fluxes to the water column declined across all sites during the first few days of the experiment, switching to a $\mathrm{NO}_{3}{ }^{-}$influx after a couple of days (Fig. 2a). The influx of $\mathrm{NO}_{3}{ }^{-}$ peaked after $5 \mathrm{~d}$ of incubation and gradually declined to zero by the end of the experiment, although there was still a small concentration of $\mathrm{NO}_{3}{ }^{-}$present in the water column (Table 3).

There was a significant interaction between site and time for $\mathrm{NH}_{4}{ }^{+}$fluxes (Table 2). During the first $3 \mathrm{~d}$ of the incubation, $\mathrm{NH}_{4}{ }^{+}$effluxed from GB sedi- ments, in contrast to RB and EB sediments, which absorbed $\mathrm{NH}_{4}{ }^{+}$(Fig. 2b). As the core water became hypoxic $\mathrm{NH}_{4}{ }^{+}$fluxes out of the sediments increased, particularly from GB and RB sediments. Efflux peaked by Day 15 in GB sediments and by Day 22 in RB sediments, after which $\mathrm{NH}_{4}{ }^{+}$release declined in both. The maximum efflux of $\mathrm{NH}_{4}{ }^{+}$from EB sediments occurred after Day 22 and continued until the end of the experiment, albeit at relatively low rates.

Denitrification $\left(\mathrm{N}_{2}\right.$ flux) varied significantly over time but not between sites (Table 2). Denitrification increased across all sites within the first $24 \mathrm{~h}$ and was followed by a decline the next day (Fig. 2c). As the overlying waters became hypoxic and $\mathrm{NO}_{3}{ }^{-}$was taken up by the sediments, all sites experienced a secondary peak in $\mathrm{N}_{2}$ production that steadily declined to zero over the following $2 \mathrm{wk}$.

DNE varied significantly between sites and with time (Table 2). The DNE rose in all sediments during the first day, as $\mathrm{N}_{2}$ fluxes increased and $\mathrm{NO}_{3}{ }^{-}$ decreased (Fig. 2d). DNE continued to increase in RB and EB sediments on Day 2, but fell in GB sediments. 
a
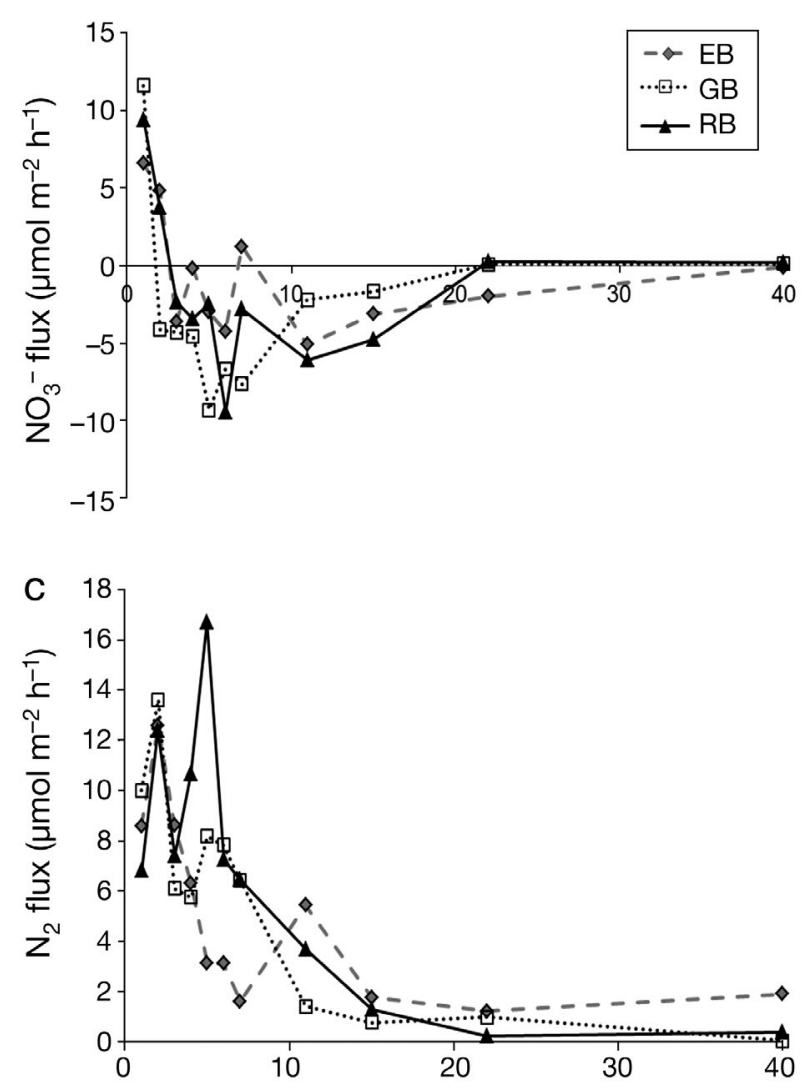

b
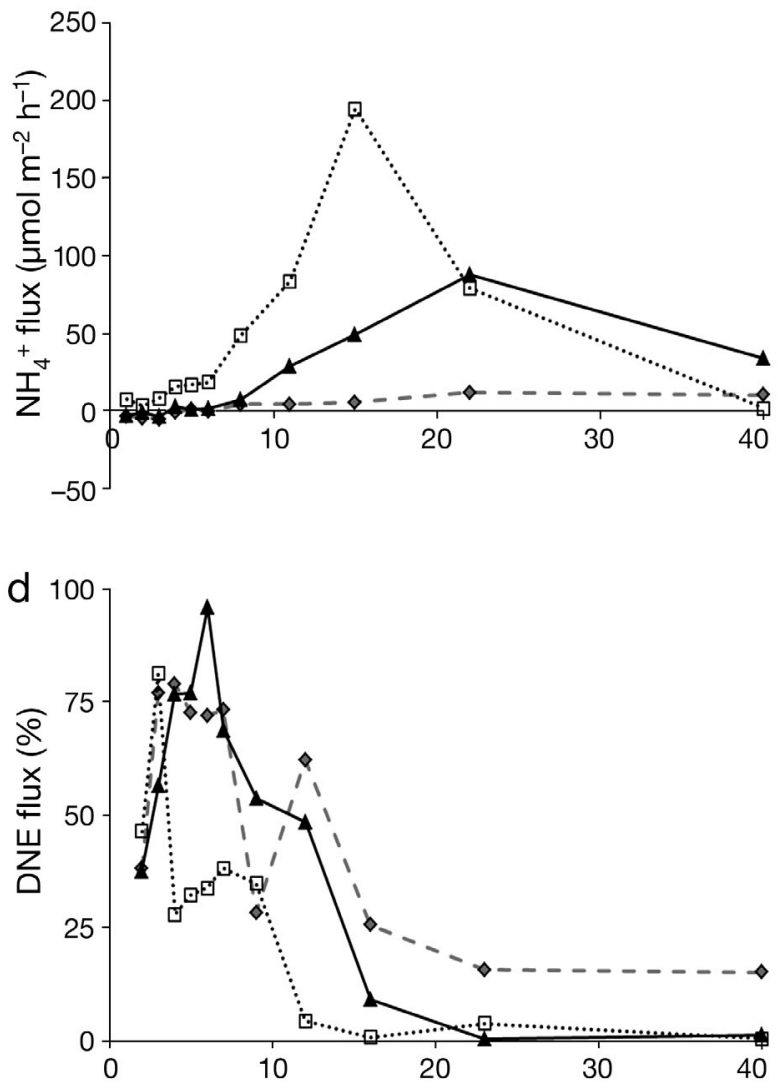

Incubation time (d)

Fig. 2. Flux of (a) $\mathrm{NO}_{3}{ }^{-}$, (b) $\mathrm{NH}_{4}{ }^{+}$and (c) $\mathrm{N}_{2}$, and (d) denitrification efficiency (DNE) of sediments collected from 3 bays in the Derwent estuary and incubated in laboratory cores in the dark for 40 d. RB: Ralph's Bay; GB: Geilston Bay; EB: Elwick Bay

RB DNE rose to a peak on Day 6 before rapidly declining, whereas EB and GB DNE were fairly stable from Days 4 to 7 . By Day 8 the DNE across all sites began to decline, although there was a brief increase in EB DNE on Day 12, matching a slight peak in $\mathrm{N}_{2}$ efflux from these sediments at that time. The rapid decline in RB and GB DNE corresponded with a rise in $\mathrm{NH}_{4}{ }^{+}$efflux from those sediments.

Table 3. Average cumulative nutrient concentration $\left(\mu \mathrm{g} \mathrm{l}^{-1}\right) \pm \mathrm{SE}$ measured in the water column of 5 replicate sediment cores collected from each of 3 sites within the Derwent estuary, and incubated under sealed conditions for 40 d. RB: Ralph's Bay; GB: Geilston Bay; EB: Elwick Bay

\begin{tabular}{|c|c|c|c|c|c|c|c|c|c|}
\hline \multirow{2}{*}{ Day } & \multicolumn{3}{|c|}{ EB } & \multicolumn{3}{|c|}{$-\mathrm{GB}-$} & \multirow[b]{2}{*}{$\mathrm{NO}_{3}^{-}$} & \multirow{2}{*}{$\begin{array}{l}-\mathrm{RB}- \\
\mathrm{NH}_{4}{ }^{+}\end{array}$} & \multirow[b]{2}{*}{$\mathrm{PO}_{4}{ }^{3-}$} \\
\hline & $\mathrm{NO}_{3}^{-}$ & $\mathrm{NH}_{4}{ }^{+}$ & $\mathrm{PO}_{4}{ }^{3-}$ & $\mathrm{NO}_{3}^{-}$ & $\mathrm{NH}_{4}{ }^{+}$ & $\mathrm{PO}_{4}{ }^{3-}$ & & & \\
\hline 1 & $59 \pm 1$ & $34 \pm 7$ & $9 \pm 1$ & $67 \pm 1$ & $38 \pm 1$ & $11 \pm 1$ & $69 \pm 2$ & $35 \pm 6$ & $17 \pm 1$ \\
\hline 2 & $76 \pm 9$ & $28 \pm 5$ & $9 \pm 1$ & $97 \pm 29$ & $55 \pm 14$ & $14 \pm 3$ & $95 \pm 5$ & $32 \pm 6$ & $20 \pm 1$ \\
\hline 3 & $91 \pm 10$ & $19 \pm 7$ & $10 \pm 2$ & $93 \pm 26$ & $64 \pm 24$ & $17 \pm 3$ & $108 \pm 16$ & $33 \pm 9$ & $24 \pm 3$ \\
\hline 4 & $87 \pm 15$ & $10 \pm 4$ & $8 \pm 1$ & $88 \pm 20$ & $83 \pm 36$ & $19 \pm 4$ & $108 \pm 20$ & $28 \pm 8$ & $24 \pm 3$ \\
\hline 5 & $90 \pm 14$ & $9 \pm 2$ & $8 \pm 1$ & $82 \pm 35$ & $118 \pm 53$ & $22 \pm 5$ & $105 \pm 23$ & $37 \pm 19$ & $28 \pm 5$ \\
\hline 6 & $88 \pm 13$ & $13 \pm 3$ & $8 \pm 1$ & $66 \pm 40$ & $155 \pm 80$ & $22 \pm 6$ & $105 \pm 25$ & $41 \pm 21$ & $28 \pm 4$ \\
\hline 7 & $82 \pm 16$ & $13 \pm 2$ & $8 \pm 1$ & $56 \pm 32$ & $196 \pm 144$ & $23 \pm 6$ & $89 \pm 25$ & $46 \pm 25$ & $29 \pm 4$ \\
\hline 8 & $91 \pm 17$ & $32 \pm 10$ & $8 \pm 1$ & $27 \pm 14$ & $402 \pm 459$ & $35 \pm 29$ & $81 \pm 28$ & $79 \pm 56$ & $34 \pm 8$ \\
\hline 11 & $62 \pm 17$ & $61 \pm 20$ & $10 \pm 3$ & $18 \pm 2$ & $923 \pm 859$ & $58 \pm 35$ & $45 \pm 48$ & $265 \pm 394$ & $50 \pm 29$ \\
\hline 15 & $39 \pm 16$ & $111 \pm 35$ & $10 \pm 1$ & $8 \pm 2$ & $2533 \pm 1139$ & $134 \pm 71$ & $9 \pm 1$ & $680 \pm 634$ & $71 \pm 50$ \\
\hline 22 & $14 \pm 8$ & $291 \pm 107$ & $13 \pm 3$ & $13 \pm 6$ & $3678 \pm 1197$ & $185 \pm 111$ & $18 \pm 7$ & $1956 \pm 797$ & $178 \pm 56$ \\
\hline 40 & $13 \pm 5$ & $666 \pm 195$ & $17 \pm 9$ & $22 \pm 11$ & $3734 \pm 895$ & $393 \pm 77$ & $29 \pm 15$ & $3134 \pm 349$ & $393 \pm 77$ \\
\hline
\end{tabular}



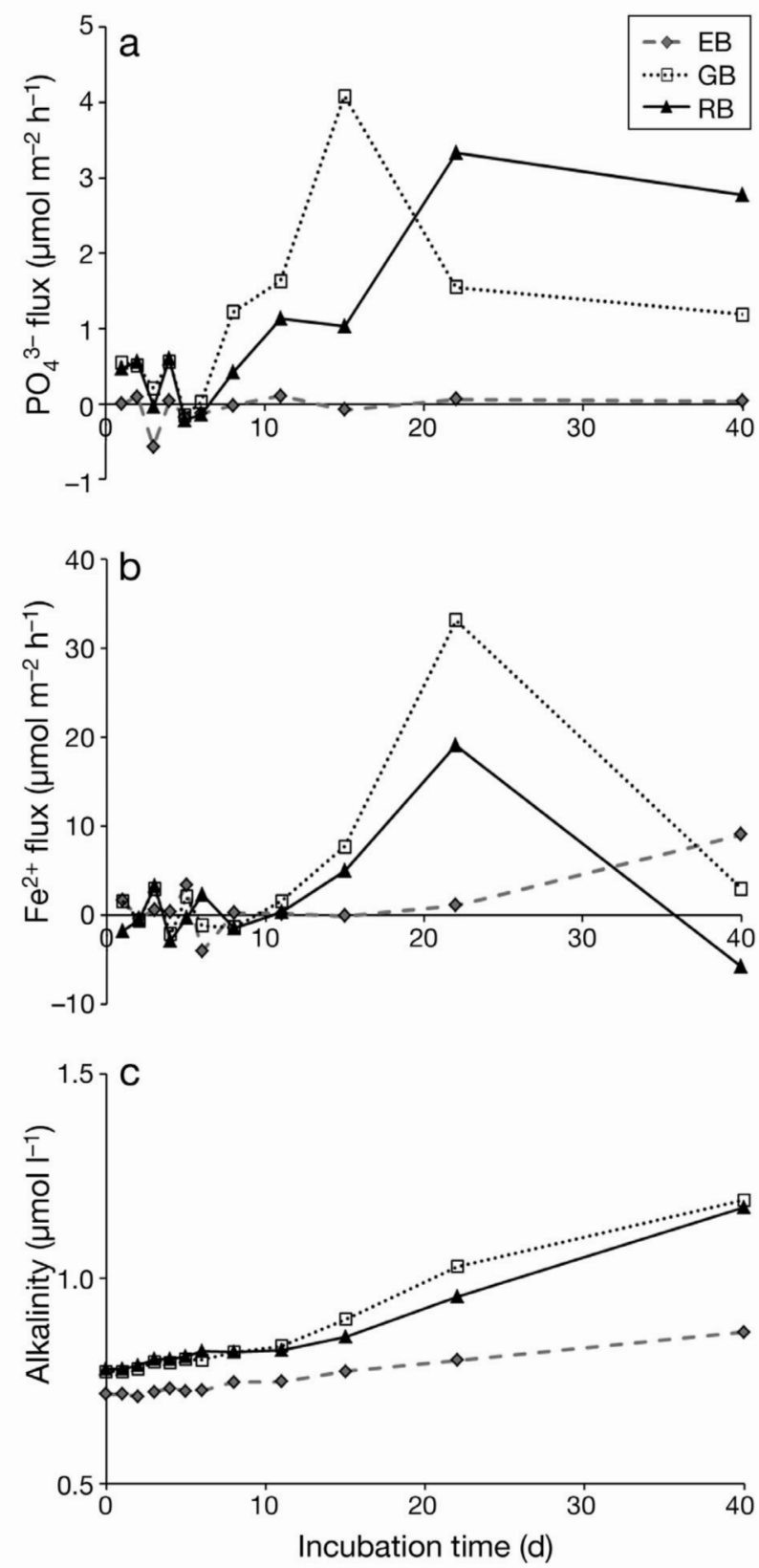

Fig. 3. Flux of (a) $\mathrm{PO}_{4}{ }^{3-}$ and (b) Fe from sediments, and (c) total alkalinity in waters overlying sediments collected from 3 bays in the Derwent estuary and incubated in laboratory cores in the dark for 40 d. RB: Ralph's Bay; GB: Geilston Bay; EB: Elwick Bay

\section{Phosphate fluxes}

Phosphate release also showed an interaction between site and time (Table 2). Fluxes were not significantly different in the first $5 \mathrm{~d}$, but once the core waters became hypoxic, $\mathrm{PO}_{4}{ }^{3-}$ was released from GB sediments at a much greater rate, 4 times higher than the flux from RB sediments at that time (Fig. 3a). By
Day 22, $\mathrm{PO}_{4}{ }^{3-}$ flux from $\mathrm{RB}$ sediments had increased and GB declined. The flux of $\mathrm{PO}_{4}{ }^{3-}$ from EB sediments was negligible throughout the experiment.

\section{Fe release}

There was an interaction between site and time for Fe fluxes (Table 2, Fig. 3b). GB and RB sediments released Fe from Day 15, and Fe peaked at Day 22, and fluxes were twice as high from GB sediments and then declined towards zero by Day 40. Fe fluxed from EB sediments at a significantly lower rate than from the other 2 sites, but continued to efflux up to the end of the experiment.

\section{Sulphide fluxes}

At the start of the experiment $\mathrm{S}^{2-}$ concentrations were small in EB and GB sediments and undetectable in RB sediments (Table 1). After $40 \mathrm{~d}$ of $\mathrm{O}_{2}$ depletion, $\mathrm{S}^{2-}$ concentrations increased ten-fold in the EB sediments; nevertheless, the concentration was still small. GB sediments had the highest initial concentration of $\mathrm{S}^{2-}$, but the concentration did not significantly increase through the duration of the experiment. Sulphide in RB sediments increased from undetectable levels to a very low concentration of $0.3 \mathrm{mg} \mathrm{kg}^{-1}$. At the end of the experiment the accumulation of $\mathrm{S}^{2-}$ in the core waters was low. Concentrations were too small to be detected in EB cores, although $\mathrm{H}_{2} \mathrm{~S}$ was detected by smell and a black coating of the surface sediment was observed, probably owing to colloidal FeS deposition. Alkalinity concentrations increased in GB and RB core waters from Day 15 onwards suggesting that sulphate reduction was occurring (Fig. 3c). EB cores showed a slightly increased alkalinity from Day 22 onwards.

\section{DISCUSSION}

Sediments collected from 3 sites within the Derwent estuary responded differently to a $40 \mathrm{~d} \mathrm{O}_{2}$ depletion event. Fluxes of $\mathrm{NO}_{3}{ }^{-}$and $\mathrm{N}_{2}$ did not differ between sites; however, the effects of hypoxia on sediment metabolism and $\mathrm{NH}_{4}{ }^{+}$and $\mathrm{PO}_{4}{ }^{3-}$ release appeared to be modified, in part, by the initial macrofauna component of the sites and the quality of the $\mathrm{OM}$ within the sediments. $\mathrm{O}_{2}$ consumption by macrofauna is likely to be partly responsible for the faster rate of DO decline detected during the first few days 
of the experiment. GB sediments had the highest initial $\mathrm{O}_{2}$ consumption rate and demonstrated the most rapid descent into hypoxic and then anoxic conditions. The onset of hypoxia in RB sediments was comparatively slower than at the other 2 sites. This was surprising as the overall biomass of macrofauna at this site was higher than at GB, and consequently $\mathrm{O}_{2}$ consumption would be predicted to be higher (Clough et al. 2005). However, we identified differences in macrofauna functional groups between RB and $\mathrm{GB}_{i} \mathrm{RB}$ was dominated by burrowing infauna $(85 \%)$, whereas half of the fauna sampled from the GB sediments was surface-associated epifauna. The infauna burrows in RB may have provided an oxic reservoir within the sediments (Conley et al. 2009a) and reduced the $\mathrm{O}_{2}$ concentration gradient between the sediment and the overlying water, thereby reducing the diffusive influx of $\mathrm{O}_{2}$.

In addition, bioturbation and irrigation by burrowing fauna tends to mix OM deeper into the sediment, increasing the proportion of mineralisation occurring via $\mathrm{Fe}, \mathrm{Mn}$ and $\mathrm{SO}_{4}{ }^{2-}$, thereby reducing $\mathrm{O}_{2}$ consumption (Conley et al. 2007). In the absence of burrowing infauna, OM mineralisation would tend to occur at the surface resulting in a more rapid depletion of $\mathrm{O}_{2}$ from bottom waters (Conley et al. 2007). EB sediments, with their paucity of macrofauna, experienced the slowest DO decline.

Nitrate and $\mathrm{N}_{2}$ fluxes varied across time, but not markedly between sites, suggesting that the effects of DO depletion on nitrification and denitrification were similar across the 3 sites. After $2 \mathrm{~d}_{1} \mathrm{NO}_{3}{ }^{-}$consumption exceeded production, potentially indicating sediment nitrification inhibition, although nitrification was not measured directly. Initially hypoxic bottom water conditions had a stimulatory effect on sediment denitrification, as $\mathrm{N}_{2}$ fluxes doubled in $\mathrm{GB}$ and EB sediments and tripled in RB sediments. However, after a week of $\mathrm{O}_{2}$ depletion, $\mathrm{N}_{2}$ efflux slowed and the DNE ratio declined, suggesting that denitrifier activity had been suppressed. This is consistent with patterns of denitrification activity measured from hypoxic zones in the Gulf of Mexico where denitrification was observed to peak at sites with DO concentrations between 1 and $3 \mathrm{mg} \mathrm{l}^{-1}$ and was significantly reduced at sites where DO was below $1 \mathrm{mg} \mathrm{l}^{-1}$ (Childs et al. 2002).

Ammonium effluxed from GB and RB sediments from Day 8; the GB effluxes peaked earlier and were twice as high as those in the RB sediments. The release of $\mathrm{NH}_{4}{ }^{+}$during hypoxia has been related to decreases in sediment nitrifier demand (Conley et al. 2007) as well as the stimulation of DNRA (McCarthy et al. 2008). The peak release of $\mathrm{NH}_{4}{ }^{+}$from GB sediments on Day 16 coincided with an influx of $\mathrm{NO}_{3}{ }^{-}$ that was greater than the concomitant efflux of $\mathrm{N}_{2}$. This could be explained by DNRA microorganisms outcompeting denitrifiers for the available $\mathrm{NO}_{3}{ }^{-}$. At the same time alkalinity increased, indicating that sulphate reduction to sulphide was occurring. Not only can the presence of free sulphide inhibit denitrification (Brunet \& Garcia-Gil 1996, Burgin \& Hamilton 2007), but when $\mathrm{NO}_{3}{ }^{-}$is limited, sulphatereducing bacteria capable of DNRA may outcompete denitrifiers for the available $\mathrm{NO}_{3}{ }^{-}$(Brunet \& GarciaGil 1996, Rysgaard et al. 1996, Kelso et al. 1997).

Nevertheless, the amount of $\mathrm{NH}_{4}{ }^{+}$released in the GB and $\mathrm{RB}$ cores far outstripped the amount of $\mathrm{NO}_{3}{ }^{-}$ absorbed. Also, the $\mathrm{NH}_{4}{ }^{+}$fluxes closely matched $\mathrm{PO}_{4}{ }^{3-}$ fluxes and increases in the CRQ, presumably resulting from the decomposition of dead animals within the cores. The continued rise in the RB CRQ ratio might therefore reflect the extended decomposition of the greater initial biomass of biota in the RB sediments, compared with that in the GB sediments.

After Day 22, $\mathrm{NH}_{4}{ }^{+}$production in $\mathrm{GB}$ and $\mathrm{RB}$ cores rapidly declined towards zero, signalling the exhaustion of OM supplies for remineralisation. In contrast $\mathrm{PO}_{4}{ }^{3-}$ fluxes, although diminished, remained fairly high, particularly in RB cores. This was most probably due to the continued reductive release of $\mathrm{PO}_{4}{ }^{3-}$ from ferric oxyhydroxide complexes. Concomitantly, dissolved ferrous iron was detected in GB and RB cores from Day 15, peaking on Day 22 before declining towards zero by Day 40 . These interconnected patterns of Fe and $\mathrm{PO}_{4}{ }^{3-}$ release closely match those measured during a similar $40 \mathrm{~d}$ sealed core incubation of sediment from Aarhus Bay in Sweden (Jørgensen \& Richardson 1996).

Sulphate reduction reactions produce $\mathrm{S}^{2-}$ ions that strongly bind Fe into stable ferric sulphides (Burdige 2006), and the data suggest that this was starting to happen by Day 22, as $\mathrm{PO}_{4}{ }^{3-}$ began to decline. This binding of $\mathrm{Fe}$ and $\mathrm{S}^{2-}$ could explain the lack of increase in $\mathrm{S}^{2-}$ in the sediment and overlying water of GB cores under the fully anoxic conditions at the end of the experiment, compared with the significant increase in these ions in the waters overlying the RB sediments. The availability of reactive iron has been proposed as a mechanism for buffering toxic free sulphide in marine sediments and may be important for ecosystem recovery after a hypoxic/anoxic episode (Lehtoranta et al. 2009). Areas with high iron loads such as GB may therefore have a greater capacity for resilience to the deleterious impacts of an extended hypoxic/anoxic episode as a result of their ability to 
bind and mitigate toxic $\mathrm{S}^{2-}$. The downside to this is that if soluble ferrous iron stores become fixed as insoluble iron sulphides, subsequent releases of $\mathrm{PO}_{4}{ }^{3-}$ from reduced ferric oxyhydroxide complexes and OM mineralisation would become more mobile and bioavailable, exacerbating eutrophication (Heijs et al. 2000, Zak et al. 2006).

In contrast to $\mathrm{GB}$ and $\mathrm{RB}$ sediments, $\mathrm{NH}_{4}{ }^{+}, \mathrm{PO}_{4}{ }^{3-}$ and $\mathrm{CO}_{2}$ release from EB sediments was negligible, reflecting the lack of readily digestible OM and dead macrofauna. OM at this site is dominated by terrigenous material that is hard to digest, sourced either from catchment inputs or from the PM situated upstream from this site. The high C:N ratio of these sediments $(E B=21)$ is close to that measured for the wood fibre historically released as primary effluent from the upstream PM (28) (Oakes et al. 2011), whereas the $\mathrm{C}: \mathrm{N}$ ratios of the other 2 sites $(\mathrm{GB}=13$ and $\mathrm{RB}=9$ ) were closer to degraded phytodetritus (Ferguson \& Eyre 2010). The lack of $\mathrm{PO}_{4}{ }^{3-}$ release from reduced oxyhydroxide complexes in EB sediments may be due to the lower salinity conditions at this site. Hyposaline sediments have been reported to have a greater capacity to immobilise P (Caraco et al. 1990) (although these reports are from oxic freshwater systems). Iron release was also much slower from EB sediments and this, in combination with the low concentrations of sulphide measured in both the sediments and water column, suggest there are higher initial concentrations of stable iron pyrites owing to the lower redox potential of these sediments.

\section{Limitations and implications}

Conducting experiments in sealed cores in the laboratory inevitably means that conditions are quite different from those in the natural environment. In this experiment, the cores were sealed in order to lower the DO concentration of the water column slowly in an attempt to mimic the gradual onset of hypoxia and the descent into anoxia in the absence of $\mathrm{O}_{2}$ replenishment. The cores were collected during winter, when the DO was approximately $70 \%$ at all sites, so that we could monitor the effects of $\mathrm{O}_{2}$ depletion at the same rate between sites with different ecological properties. The main problem with this approach was that the core waters were not replenished or subject to diluting currents as they would normally be (see cumulative nutrient concentrations in Table 3). Accumulation of nutrients in the water column would have led to temporary disturbances to nutrient concentration gradients between the sediment and overlying water and potentially have increased fluxes back into the sediment owing to simple diffusion. In addition, macrofauna in these cores were effectively trapped and unable to move away from the adverse conditions. Mortality of animals that would normally exhibit avoidance, and the decomposition of dead animals that would likely be consumed by scavengers, would have artificially increased the nutrient loads released into the core waters.

Conducting the experiment in winter allowed us to start with standard normoxic conditions across the sites, but removed the seasonal component of increased phytodetritus input observed in spring and summer months. It would be interesting to repeat the experiment in the summer to ascertain seasonal effects. In addition, dark incubations prevent primary production by microphytobenthos that, in the natural environment, could inhibit hypoxia development and capture nutrients released from the sediment before they reach the overlying water column. A light-dark experimental regime may capture this effect more effectively.

This study still provides useful information regarding the potential effects of environmental patchiness on the relative changes to nutrient fluxes during hypoxic and anoxic episodes (see summary, Fig. 4). As expected, extended DO depletion in the experimental cores led to the flux of large quantities of $\mathrm{NH}_{4}{ }^{+}$and $\mathrm{PO}_{4}{ }^{3-}$ from the sediments to the water column. In natural estuarine waters the consequence of this flux of bioavailable nutrients would be the stimulation of algal blooms, with the possible development of eutrophication and further depletion of DO. However, the main release of bioavailable nutrients occurred after $15 \mathrm{~d}$ of DO depletion and it is likely that some replenishment of bottom waters would occur by that stage in a temperate estuary, where wind-driven mixing is prevalent.

Our results suggest that small-scale environmental heterogeneity in estuaries cause some areas to be more vulnerable to the effects of hypoxia than others. The cores collected from GB descended more rapidly into hypoxia resulting in an early and substantial release of bioavailable $\mathrm{NH}_{4}{ }^{+}$. The GB sediments are highly polluted with heavy metals, derived from a local zinc refinery, and it is possible that this contamination has led to the loss of burrowing and bioturbating infauna. The onset of hypoxia was delayed at the site with the greater diversity of burrowing macrofauna (RB) compared with the site dominated by epifauna (GB), suggesting a greater level of resilience at the RB site. This highlights the benefit of 

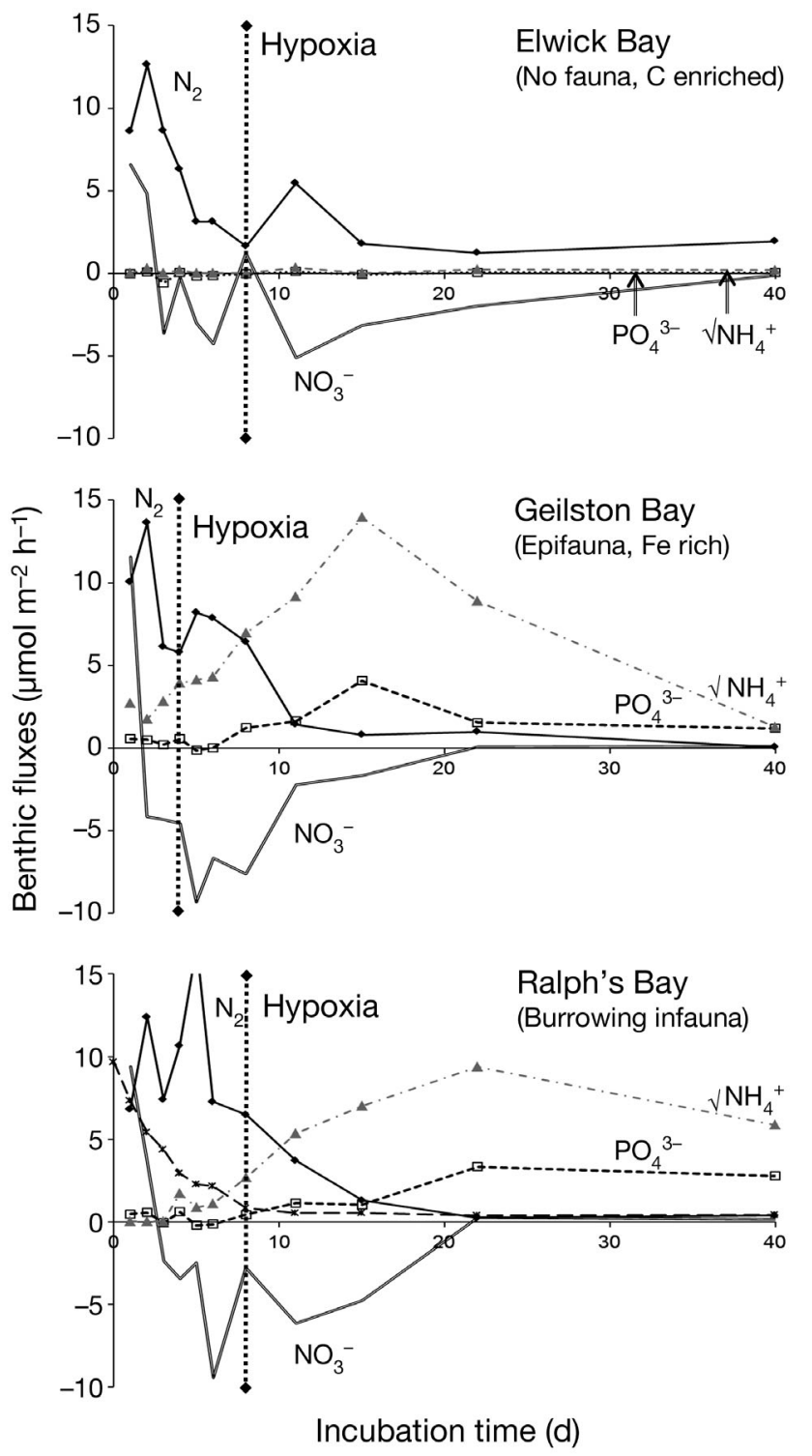

Fig. 4. Summary of fluxes between sites. Geilston Bay (GB) became hypoxic (dashed vertical line) more rapidly than Elwick Bay (EB) and Ralph's Bay (RB), reflecting the buffering capacity of infauna burrows in RB and the absence of macrofauna respiration in EB. As dissolved oxygen decreased, $\mathrm{NO}_{3}{ }^{-}$fluxed into the sediment. When $\mathrm{NO}_{3}{ }^{-}$influxes declined, so did $\mathrm{N}_{2}$ effluxes, suggesting a decrease in denitrification owing to substrate limitation. Decomposition of small epifauna in GB sediments occurred rapidly, releasing large concentrations of $\mathrm{NH}_{4}{ }^{+}$and $\mathrm{PO}_{4}{ }^{3-}$. Larger burrowing infauna in RB sediments decomposed more slowly, creating a more sustained release of nutrients. EB, the most environmentally degraded of the sites in this study, was the most resilient to hypoxia (in terms of releasing bioavailable nutrients); this appears to be a result of the paucity of macrofauna and lack of labile organic matter at this site maintaining functional diversity and particularly a healthy infaunal community within benthic environments. The EB sediments appeared to be similarly resilient to the onset of hypoxia; however, in this case this was because there was little biological material of any significance to be broken down, as the sediments contained neither infauna nor substantial epifauna.

Acknowledgements. This work was made possible owing to funding support from an ARC Linkage grant (LP0770222) to D.J.R., B.D.E. and M.J.K., and an ARC Discovery Grant (DP0878568) awarded to B.D.E. Norske-Skog Boyer and the Derwent Estuary Program provided financial and in-kind assistance. We thank A. Pender of Tasmanian Aquaculture and Fisheries Institute (TAFI) for excellent field and laboratory assistance and G. Napthali of Analytical Services Tasmania (AST) for nutrient sample processing.

\section{LITERATURE CITED}

Abell GCJ, Banks JL, Ross DJ, Keane JP, Robert SS, Revill AT, Volkman JK (2011) Effects of estuarine sediment hypoxia on nitrogen fluxes and ammonia oxidizer gene transcription. FEMS Microbiol Ecol 75:111-122

Almgren T, Dryssen D, Fonselius S (1983) Determination of alkalinity and total carbonate. In: Grasshoff $\mathrm{K}$, Erhardt M, Kremling K (eds) Methods of seawater analysis. Verlag Chemie, Weinheim, p 99-123

Braeckman U, Provoost P, Gribsholt B, Van Gansbeke D and others (2010) Role of macrofauna functional traits and density in biogeochemical fluxes and bioturbation. Mar Ecol Prog Ser 399:173-186

Brunet RC, Garcia-Gil LJ (1996) Sulfide-induced dissimilatory nitrate reduction to ammonia in anaerobic freshwater sediments. FEMS Microbiol Ecol 21:131-138

Burdige DJ (2006) Geochemistry of marine sediments. Princeton University Press, Princeton, NJ

Burgin AJ, Hamilton SK (2007) Have we overemphasized the role of denitrification in aquatic ecosystems? A review of nitrate removal pathways. Front Ecol Environ 5:89-96

Butler ECV (2006) The tail of two rivers in Tasmania: the Derwent and Huon estuaries. In: Wangersky PJ (ed) Estuaries. The handbook of environmental chemistry, Vol 5, Part H. Springer-Verlag, Berlin, p 1-49

- Caraco N, Cole J, Likens GE (1990) A comparison of phosphorus immobilization in sediments of freshwater and coastal marine systems. Biogeochemistry 9:277-290

Childs CR, Rabalais NN, Turner RE, Proctor LM (2002) Sediment denitrification in the Gulf of Mexico zone of hypoxia. Mar Ecol Prog Ser 240:285-290

Christensen PB, Rysgaard S, Sloth NP, Dalsgaard T, Schwærter S (2000) Sediment mineralization, nutrient fluxes, denitrification and dissimilatory nitrate reduction to ammonium in an estuarine fjord with sea cage trout farms. Aquat Microb Ecol 21:73-84

> Clough LM, Renaud PE, Ambrose WG Jr (2005) Impacts of water depth, sediment pigment concentration, and benthic macrofaunal biomass on sediment oxygen demand in the western Arctic Ocean. Can J Fish Aquat Sci 62: 1756-1765 
Conley DJ, Carstensen J, Ærtebjerg G, Christensen PB, Dalsgaard T, Hansen JLS, Josefson AB (2007) Long-term changes and impacts of hypoxia in Danish coastal waters. Ecol Appl 17:S165-S184

$>$ Conley D, Carstensen J, Vaquer-Sunyer R, Duarte C (2009a) Ecosystem thresholds with hypoxia. Hydrobiologia 629: 21-29

- Conley DJ, Björck S, Bonsdorff E, Carstensen J and others (2009b) Hypoxia-related processes in the Baltic Sea. Environ Sci Technol 43:3412-3420

Dalsgaard T, Thamdrup B, Canfield DE (2005) Anaerobic ammonium oxidation (anammox) in the marine environment. Res Microbiol 156:457-464

> Diaz RJ (2001) Overview of hypoxia around the world. J Environ Qual 30:275-281

Eaton AD, Clesceri LS, Rice EW, Greenberg AE, Franson MAH (eds) (2005) Standard methods for the examination of water and wastewater, 21st edn. American Public Health Association, American Water Works Association and Water Environment Federation, Washington, DC

Eyre BD, Ferguson AJP (2002) Comparison of carbon production and decomposition, benthic nutrient fluxes and denitrification in seagrass, phytoplankton, benthic microalgae- and macroalgae-dominated warm-temperate Australian lagoons. Mar Ecol Prog Ser 229:43-59

Eyre BD, Ferguson AJP (2009) Denitrification efficiency for defining critical loads of carbon in shallow coastal ecosystems. Hydrobiologia 629:137-146

Eyre BD, Rysgaard S, Dalsgaard T, Christensen PB (2002) Comparison of isotope pairing and $\mathrm{N}_{2}$ :Ar methods for measuring sediment denitrification rates - assumptions, modifications, and implications. Estuaries 25:1077-1087

> Ferguson AJP, Eyre BD (2010) Carbon and nitrogen cycling in a shallow productive sub-tropical coastal embayment (western Moreton Bay, Australia): the importance of pelagic-benthic coupling. Ecosystems 13:1127-1144

> Ferguson A, Eyre BD, Gay JM (2004) Nutrient cycling in the sub-tropical Brunswick estuary, Australia. Estuaries 27: 1-17

Gilbert F, Souchu P, Bianchi M, Bonin P (1997) Influence of shellfish farming activities on nitrification, nitrate reduction to ammonium and denitrification at the watersediment interface of the Thau lagoon, France. Mar Ecol Prog Ser 151:143-153

Heijs SK, Azzoni R, Giordani G, Jonkers HM, Nizzoli D, Viaroli P, van Gemerden H (2000) Sulfide-induced release of phosphate from sediments of coastal lagoons and the possible relation to the disappearance of Ruppia sp. Aquat Microb Ecol 23:85-95

> Hietanen S, Lukkari K (2007) Effects of short-term anoxia on benthic denitrification, nutrient fluxes and phosphorus forms in coastal Baltic sediment. Aquat Microb Ecol 49: 293-302

Howarth RW, Marino R, Lane J, Cole JJ (1988) Nitrogen fixation in freshwater, estuarine, and marine ecosystems. 1. Rates and importance. Limnol Oceanogr 33:669-687

Jordan TE, Cornwell JC, Boynton WR, Anderson JT (2008) Changes in phosphorus biogeochemistry along an estuarine salinity gradient: the iron conveyer belt. Limnol Oceanogr 53:172-184

Jørgensen BB, Richardson K (eds) (1996) Eutrophication in coastal marine ecosystems, Vol 52. American Geophysical Union, Washington, DC

Kana TM, Sullivan MB, Cornwell JC, Groszkowski KM (1998) Denitrification in estuarine sediments determined by membrane inlet mass spectrometry. Limnol Oceanogr 43:334-339

Kelso B, Smith RV, Laughlin RJ, Lennox SD (1997) Dissimilatory nitrate reduction in anaerobic sediments leading to river nitrite accumulation. Appl Environ Microbiol 63: 4679-4685

> Kemp WM, Sampou P, Caffrey J, Mayer M, Henriksen K, Boynton WR (1990) Ammonium recycling versus denitrification in Chesapeake Bay sediments. Limnol Oceanogr 35:1545-1563

Kemp WM, Testa JM, Conley DJ, Gilbert D, Hagy JD (2009) Temporal responses of coastal hypoxia to nutrient loading and physical controls. Biogeosciences 6: 2985-3008

Lehtoranta J, Ekholm P, Pitkänen H (2009) Coastal eutrophication thresholds: a matter of sediment microbial processes. Ambio 38:303-308

Macleod C, Helidoniotis F (2005) Biological status of the Derwent and Huon estuaries. In: TAFI Internal/Technical Report. Tasmanian Aquaculture and Fisheries Institute, Hobart. www.tafi.org.au/publications/NRMHuonDerwent Report.pdf

> Macleod CK, Crawford CM, Moltschaniwskyj NA (2004) Assessment of long term change in sediment condition after organic enrichment: defining recovery. Mar Pollut Bull 49:79-88

McCarthy M, McNeal K, Morse J, Gardner W (2008) Bottom-water hypoxia effects on sediment-water interface nitrogen transformations in a seasonally hypoxic, shallow bay (Corpus Christi Bay, TX, USA). Estuar Coasts 31: $521-531$

> Middelburg JJ, Levin LA (2009) Coastal hypoxia and sediment biogeochemistry. Biogeosciences 6:1273-1293

Oakes JM, Eyre BD, Ross DJ, Turner SD (2010) Stable isotopes trace estuarine transformations of carbon and nitrogen from primary- and secondary-treated paper and pulp mill effluent. Environ Sci Technol 44:7411-7417

> Oakes JM, Eyre BD, Ross DJ (2011) Short-term enhancement, and long-term suppression, of denitrification in estuarine sediments receiving primary- and secondarytreated paper and pulp mill discharge. Environ Sci Technol 45:3400-3406

> Peña MA, Katsev S, Oguz T, Gilbert D (2010) Modeling dissolved oxygen dynamics and hypoxia. Biogeosciences 7 : 933-957

Quinn G, Keough M (2002) Experimental design and data analysis for biologists. Cambridge University Press, Cambridge

Rabalais NN, Díaz RJ, Levin LA, Turner RE, Gilbert D, Zhang J (2010) Dynamics and distribution of natural and human-caused hypoxia. Biogeosciences 7:585-619

Rochford DJ (1951) Studies in estuarine hydrology I: introduction and comparative features. Aust J Mar Freshw Res 2:1-116

- Roy RN, Roy LN, Vogel KM, Porter-Moore KM and others (1993) The dissociation constants of carbonic acid in seawater at salinities 5 to 45 and temperatures 0 to $45^{\circ} \mathrm{C}$. Mar Chem 44:249-267

Rysgaard S, Risgaard-Petersen N, Sloth NP (1996) Nitrification, denitrification, and nitrate ammonification in sediments of two coastal lagoons in southern France. Hydrobiologia 329:133-141

Schaanning MT, Hylland K, Eriksen DØ, Bergan TD, Gunnarson JS, Skei J (1996) Interactions between eutrophication and contaminants. II. Mobilization and bioaccu- 
mulation of $\mathrm{Hg}$ and $\mathrm{Cd}$ from marine sediments. Mar Pollut Bull 33:71-79

Silver WL, Herman DJ, Firestone MK (2001) Dissimilatory nitrate reduction to ammonium in upland tropical forest soils. Ecology 82:2410-2416

Souchu P, Gasc A, Collos Y, Vaquer A, Tournier H, Bibent B, Deslous-Paoli JM (1998) Biogeochemical aspects of bottom anoxia in a Mediterranean lagoon (Thau, France). Mar Ecol Prog Ser 164:135-146

Thomson J, Godfrey J (1985) Circulation dynamics in the Derwent Estuary. Mar Freshw Res 36:765-772

Tiedje JM (1988) Ecology of denitrification and dissimilatory nitrate reduction to ammonium. In: Zehnder AJB (ed) Environmental microbiology of anaerobes. John Wiley and Sons, New York, NY, p 179-244

Turner RE, Rabalais NN, Justic D (2008) Gulf of Mexico hypoxia: alternate states and a legacy. Environ Sci Technol 42:2323-2327

Webb AP, Eyre BD (2004) Effect of natural populations of burrowing thalassinidean shrimp on sediment irrigation, benthic metabolism, nutrient fluxes and denitrification.

Editorial responsibility: William Kemp,

Cambridge, Maryland, USA
Mar Ecol Prog Ser 268:205-220

Whitehead J, Coughanowr C, Agius J, Chrispijn J, Taylor U, Wells F (2010a) State of the Derwent Estuary 2009: a review of pollution sources, loads and environmental quality data from 2003-2009. In: Derwent Estuary Program, DPIPWE, Hobart. www.derwentestuary.org.au/ file.php?id=381)

Whitehead J, Coughanowr C, Agius J, Chrispijn J, Taylor U, Wells F (2010b) State of the Derwent Estuary 2009: a review of pollution sources, loads and environmental quality data from 2003-2009. In: Derwent Estuary Program, DPIPWE, Hobart. www.derwentestuary.org.au/ file.php?id=402

Zak D, Kleeberg A, Hupfer M (2006) Sulphate-mediated phosphorus mobilization in riverine sediments at increasing sulphate concentration, River Spree, NE Germany. Biogeochemistry 80:109-119

- Zhang J, Gilbert D, Gooday AJ, Levin L and others (2010) Natural and human-induced hypoxia and consequences for coastal areas: synthesis and future development. Biogeosciences 7:1443-1467

Submitted: May 18, 2011; Accepted: February 27, 2012 Proofs received from author(s): April 27, 2012 